January 2019

\title{
Time Has Come Today
}

Megan Price

San Jose State University, mmeprice@protonmail.com

Follow this and additional works at: https://scholarworks.sjsu.edu/ischoolsrj

Part of the Archival Science Commons, Cataloging and Metadata Commons, Collection Development and Management Commons, Information Literacy Commons, Museum Studies Commons, Scholarly Communication Commons, and the Scholarly Publishing Commons

\section{Acknowledgements}

\section{Recommended Citation}

Price, M. (2019). Time Has Come Today. School of Information Student Research Journal, 8(2). https://doi.org/10.31979/2575-2499.080201 Retrieved from https://scholarworks.sjsu.edu/ischoolsrj/ vol8/iss $2 / 1$

This article is brought to you by the open access Journals at SJSU ScholarWorks. It has been accepted for inclusion in School of Information Student Research Journal by an authorized administrator of SJSU ScholarWorks. For more information, please contact scholarworks@sjsu.edu. 


\section{Time Has Come Today}

\section{Keywords}

editorial

Acknowledgements 
This issue launches during a difficult time for our nation. The consequences of current events are sure to have a lasting effect on our democracy, but at this time, they remain unknown. While we have crossed over to a different sort of governing and a different sort of truth, we have also stepped into the possibility of immense growth and change. We know, as burgeoning and current librarians, archivists, and information scientists, that accuracy is important, information is valuable, and knowledge is power. These principles rest at the heart of our work, and so this point in time provides us with the opportunity to shake things up, to do things differently, to be more inclusive, and to get involved.

The authors in this, the SRJ's $16^{\text {th }}$ issue, ask important questions to support this involvement: How can dynamic collaborations between researchers and practitioners move our field forward? How can public librarians and our allies most effectively advocate for libraries and, therefore, our field? How can we as archivists broaden the diversity of archives, ensuring all people are represented?

I had the great good fortune to have taken the Political Activism class with our invited contributor, Patrick Sweeney, two semesters ago. Sweeney's book, Winning Elections and Influencing Politicians for Library Funding, provided invaluable guidance on how to fight (and win!) politically for library funding. Sweeney's new book Before the Ballot: Building Political Support for Library Funding was released January 4th. Here we present a chapter to help prepare us for what will certainly be an exciting 2020 political season.

Former SRJ editor Stacy Andell contributes our first published evidence summary, guidelines for which were designed by Canada's Evidence-Based Library and Information Practice journal. Andell evaluates a bibliometric study done by Yu-Wei Chang, who examined the characteristics of articles co-authored by researchers and practitioners in LIS journals. A likely, but up until this point, rare pairing.

Author Autumn Wetli rounds the journal out with an extensive literature review on the diversity of archives. She highlights that it is not only who is represented in archives, but how they are represented, how they are selected for inclusion, from theoretical to practical process. This review calls for a method that is "focused on the promotion of social justice, is aware of its flaws and biases, while still being hopeful and forward-looking" (Wetli, 2019).

\section{Acknowledgments}

I want to start out by thanking Morgan Briles at bepress who has worked tireless with us to update the SRJ webpage. She has spent countless hours preparing the site, so that our new look could be launched with this issue. A standing ovation for the members of the editorial team whose dedication to SRJ and its authors have made this issue possible: Stephanie Akau, Stacy Andell, Channon Arabit, Claire Goldstein, Rachel Greggs, and Lisa Lowdermilk. A special thank you to our outgoing Managing Editor, Kelly Pollard, who graciously brought me on board, showed me the ropes and was an excellent partner in all aspects of SRJ's running. A warm welcome back to Rachel Greggs who starts 2019 as our new Managing Editor. A generous thank you to our advisor, Dr. Anthony Bernier; while the entire editorial team benefits from Dr. Bernier's guidance, I feel personally fortunate to have the chance to work closely with an accomplished and knowledgeable guide, making this position one of the most rewarding experiences l've had in my LIS program. And finally, to our Editorial Board, led by Director 
School of Information Student Research Journal, Vol. 8, Iss. 2 [2019], Art. 1

Sandra Hirsh and Associate Director Linda Main, and to all the faculty and staff at the iSchool, we thank you for your continued support. 